\title{
Непротивление злу - заповедь и ее практические смыслы
}

\begin{abstract}
Аннотация: Статья посвящена рассмотрению этико-философских трактовок заповеди непротивления злу (Мф. 5, 38-41). Наряду с двумя основными подходами к интерпретации заповеди (1) как абсолютного закона, вменяющего безусловный отказ от силового сопротивления любым формам зла; (2) как ограниченной в своем действии нормы, уступающей по приоритетности императиву сопротивления злу, в статье выделяется третий подход. В его рамках сама заповедь трактуется как требование активного противостояния злу. Основное внимание уделено анализу второго и третьего подходов, которые рассматриваются на материале произведений Л. Н. Толстого и публицистики И. Бродского. В статье реконструируются и исследуются аргументы, предлагаемые в рамках этих двух подходов, выявляются особенности позиций Толстого и Бродского, проводится их сравнительный анализ. Автор приходит к выводу, что хотя установки Толстого и Бродского в понимании заповеди непротивления злу изначально противоположны, оба автора настаивают на необходимости борьбы со злом. Толстой, призывая не противиться злу внешнему, подчеркивает важность боръбы человека со злом внутри самого себя. Бродский эту точку зрения не разделяет, показывая, что отказ сопротивляться любым проявлениям зла (как внутренним, так и внешним) оборачиваются расширением территории зла, а позиция непротивления злу внешнему далеко не всегда безупречна с моральной точки зрения. Основной вывод статьи состоит в том, что гуманистическая ценность идеи непротивления злу во многом определяется возможностью увидеть в этой идее сложную проблему, не допускающую простых решений.
\end{abstract}

Ключевъе слова: Лев Толстой, Иосиф Бродский, Гуго Гроций, мораль, этика, добро, зло, непротивление, ненасилие, заповедь непротивления злу.

Review: The article is devoted to the analysis of ethical and philosophical interpretations of the commandment of non-resistance to evil (Matthew 5, 38-41). Along with the two main approaches to interpretation of the commandment (1) as an absolute law that implies an unconditional refusal from a forceful resistance to all kinds of evil; or 2) as a limited rule inferior to the imperative of resistance to evil, the author of the present article describes the third approach to the problem. Within the framework of this research, the commandment is interpreted as a demand for active resistance to evil. The research provides a thorough analysis of the second and third approaches to the problem based on Leo Tolstoy's works and Joseph Brodsky's essays. In her research article Artemieva reconstructs and studies arguments offered by the aforesaid two approaches. The author defines peculiarities of Leo Tolstoy's and Joseph Brodsky's positions and carries out their comparative analysis. The author concludes that even though Tolstoy and Brodsky initially had opposite attitudes to the commandment of nonresistance to evil, both authors insisted that evil must have been resisted. Even though Tolstoy urged not to resist the external evil, he underlined how important it was to struggle against evil inside man himself. Brodsky disagreed and demonstrated that a refusal from all kinds of evil (both internal and external forms) expands the territory of evil, and nonresistance to evil is not always flawless from the moral point of view. The main conclusion of the article is that the humanistic value of the idea of nonresistance to evil is that it is a complex problem that does not have simple solutions.

Keywords: Commandment of non-resistance to evil, nonviolence, nonresistence, Leo Tolstoy, Joseph Brodsky, Hugo Grotius, morality, ethics, good, evil.

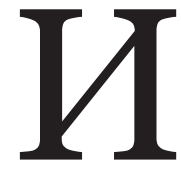

дея ненасилия возникла еще в середине I тысячелетия до н.э. и обнаруживается во всех сформировавшихся в ту эпоху культурах и религиях. В европейской культуре она выражена в христианской Заповеди непротив- ления, сформулированной в Евангелии от Матфея (Мф. 5, 38-41):

Вы слышали, что сказано: «око за око, и зуб за зуб». А Я говорю вам: не противься злому. Но кто ударит тебя в правую щеку твою, обрати к 
нему и другую; И кто захочет судиться с тобою и взять у тебя рубашку, отдай ему и верхнюю одежду; И кто принудит тебя идти с ним одно поприще, иди с ним два.

На смысл и значимость заповеди отчасти указывает ее «промежуточное» положение в данной главе: с одной стороны, она является ответом на принцип равного возмездия - талион и противопоставляется ему, с другой, заповедь непротивления предваряет заповедь любви к врагам («Вы слышали что сказано: люби ближнего твоего и ненавидь врага твоего. А Я говорю вам: любите врагов ваших, благословляйте проклинающих вас, благотворите ненавидящим вас и молитесь за обижающих вас и гонящих вас» (Мф. 5: 43-44)). Заповедь любви выражает саму сущность христианства. Она во многом разъясняет заповедь непротивления, т.е. именно заповедь любви говорит о том, что значит и как не противиться злому - не отвечать злом на зло, не держать зла на ближнего, прощать нанесенные обиды, стремиться к примирению [1]. Композиционная и содержательная соединенность двух заповедей свидетельствует о существенной значимости заповеди непротивления злу в христианстве. В силу данного обстоятельства заповедь непротивления злу была и сегодня остается предметом самых разных, часто полемичных интерпретаций. В полемике можно выделить по крайней мере две четко обозначенные позиции. Согласно первой, заповедь непротивления злу интерпретируется в буквальном смысле как абсолютный закон. В современную эпоху эта позиция была развернуто представлена Львом Толстым, и его философия ненасилия была воспринята Мохандасом Ганди, а через него позднее - Мартином Лютером Кингом и их последователями. Согласно другой позиции, данная заповедь в ее безусловном качестве противоречит обыденному опыту и моральной интуиции человека. И опыт, и моральная интуиция говорят о том, что злу необходимо сопротивляться и что именно сопротивление злу представляет собой действительно безусловный моральный императив. Сторонники данной позиции отрицают абсолютный характер заповеди непротивления, признают приоритетность требования сопротивления злу, утверждают допустимость силового сопротивления злу и стремятся сформулировать этические принципы такого сопротивления. Эти принципы указывают на допустимость и моральную обо- снованность применения силы, вместе с тем, устанавливают границы этого применения.

Данная позиция укоренена в традиции, берущей начало от Августина Блаженного, она представлена в учениях Фомы Аквинского, Гуго Гроция, русских философов Ивана Ильина, Николая Бердяева, Владимира Соловьева, в современных теориях справедливой войны.

Например, как полагал Гуго Гроций, действие заповеди непротивления ограничено следующими условиями. Во-первых, она применяется исключительно в ситуации частных отношений и не может рассматриваться как принцип устройства общественной жизни, тем самым сфера заповеди непротивления оказывается ограниченной. Во-вторых, заповедь непротивления в Евангелии конкретизируется через перечисление конкретных ситуаций, в которых не следует противиться злому. Это ситуации оскорбления, отъема имущества и принуждения. Гроций подчеркивает, что во всех этих ситуациях человеку наносится несущественный ущерб. В случае пощечины речь идет исключительно об оскорблении, причем об умеренном; оскорбление не является физическим насилием: Христос «ограничивается примером пощечины, ибо она не угрожает жизни, не калечит тела, но только служит выражением некоторого презрения, не причиняя нам дальнейшего повреждения» [5, с. 100]. В случае отъема имущества речь идет о призыве уступить имущество, каким можно пожертвовать без особого для себя ущерба, не устраивая споров и не обращаясь к посредничеству суда. Вместе с тем, отказ от имущества в пользу посягающего на него человека не должен лишать средств к существованию того, кто готов к такой жертве. В случае же принуждения к поприщу говорится лишь об одном или двух поприщах, а не о сотне поприщ, которые могли бы отвлечь человека от его собственных дел. Гроций резюмирует свое обсуждение следующим образом: «Стало быть, смысл евангельского текста в том, что в делах, которые не могут нас сильно затруднить, следует не настаивать на нашем праве, a, напротив, уступать даже больше, нежели требует противная сторона, чтобы всем стало явно как наше терпение, так и наше милосердие» [5, с. 99]. В-третьих, Гроций указывает также на то, что заповедь непротивления адресована тем, против кого непосредственно направлены злонамеренные действия. Иными словами, в заповеди задаются образ- 
цы поведения для человека, столкнувшегося с определенными (не самыми агрессивными) формами зла. Ущерб, который ему заповедуется претерпеть, может быть только личным и не должен распространяться на других. Скажем, родителю или опекуну было бы неправильно уступать имущество своих детей или подопечных, без которого те не могут существовать. В такой интерпретации заповедь непротивления нельзя считать безапелляционной, она не является общим принципом, безусловно применимым ко всем ситуациям, ее действие ограничено. Заповедь призывает человека уступать там, где это возможно, не быть воинственным, не злиться, не упорствовать в своем праве по пустякам, напротив, демонстрировать миролюбие, готовность к примирению и прощению.

Можно выделить еще одну, третью, позицию в отношении христианской заповеди непротивления. Если первая позиция налагает безусловный запрет на определенные способы сопротивления злу, а вторая исходит из безусловной приоритетности требования сопротивления злу, указывает на неабсолютный характер заповеди непротивления и обосновывает этические принципы применения силы в исключительных случаях, то особенность третьей позиции состоит в одновременном признании ключевого значения заповеди непротивления и безусловной приоритетности морального требования противостояния злу в его конкретных проявлениях. При этом сама заповедь непротивления трактуется исключительно как один из рецептов борьбы со злом, или как один из рецептов активного противления злу. Эту позицию отстаивает поэт Иосиф Бродский в «Актовой речи», произнесенной в 1984 г. в колледже Уильямса (Williams College), Массачусетс, США [2].

Бродский трижды выступал с напутственными речами в 80-е и 90-е годы прошлого века перед выпускниками университетов. Такие выступления считаются очень ответственными и приглашение выступить с напутственной речью является знаком особого признания. Две другие речи Бродского - это знаменитая «Речь на стадионе» (1988 ) - перед выпускниками Мичиганского университета, США [4] и «Похвала скуке» (1989) - перед выпускниками старейшего исследовательского университета, Дартмутского колледжа (Dartmouth College), Нью-Гэмпшир, США [3]. Бродский также выступал перед выпускницами женского колледжа в Маунт-Холиоке, США (1988)
Однако речь его не была опубликована, поскольку ирония в адрес того, что Бродский считал либеральными идолами, была расценена как неуместная и «политически некорректная» [7].

В «Речи на стадионе» Бродский определил жанр напутственной речи как заповедание, а десять заповедей - как напутственную речь [4, с. 113]. Несмотря на замечание, что подобное определение жанров «может озадачить любого напутствующего оратора», сам Бродский, по всей вероятности, был озадачен только тем, чтобы в его напутственных речах действительно содержалось важное для молодых людей, доступное не только их уму, но и чувствам заповедание. Все три речи (как и вся публицистика в целом) составляют значимую часть наследия Бродского, не менее значимую, чем его поэзия.

«Актовая речь» непосредственно посвящена заповеди непротивления злу. С ее содержанием перекликаются последние тезисы «Речи на стадионе». В «Актовой речи» Бродский противопоставляет свое понимание заповеди непротивления злу интерпретации Толстого и его учению о ненасилии в целом, а также учениям Ганди и Мартина Лютера Кинга, которые не просто разделяли многие идеи Толстого, но и считали осуществление стратегии ненасилия как в индивидуальной практике, так и в политической борьбе единственно возможной и добились на этом пути существенных успехов.

Предмет данной статьи составляют интерпретации заповеди непротивления злу Львом Толстым и Иосифом Бродским. На основе анализа особенностей подходов Толстого и Бродского я намереваюсь показать, что идея непротивления злу обладает несомненной гуманистической значимостью. Однако ее ценность, как в теоретическом, так и практическом планах, во многом определяется возможностью увидеть в этой идее сложную проблему, не допускающую простых решений.

\section{$* * *$}

Л. Н. Толстому принадлежит одно из самых последовательных учений, утверждающих непротивление как высший моральный принцип. Заповеди непротивления Толстой придавал, если не центральное, то почти центральное значение. В письме к писателю и литературному критику М. А. Энгельгардту Толстой писал: «... коротенькая, 3-я заповедь 
(Мф. 5:38-39) не противиться злу, т.е. злом не отвечать на зло - есть не скажу главное, но есть смыкающее звено всего учения, и то самое, которое старательно обходили и обходят все учения лжехристианские» [10, с. 114-115].

Христианское учение Толстой воспринимал исключительно через призму Евангелия, которое, по его мнению, представляет собой не столько изложение божественного слова, указывающего путь к спасению, или к обретению вечности, сколько жизнеучение - конкретное, доступное каждому человеку руководство к жизни. В том же письме он призывал Энгельгардта вдуматься в Евангелие не как в слово Христа или Бога, а как «самое ясное, простое, всем понятное и практическое учение о том, как надо жить каждому из нас и всем людям» [10, c. 114].

Важно иметь в виду, что заповедь непротивления злу Толстой трактовал, разумеется, не просто как требование не противиться злу вообще, а как запрет на определенные способы реагирования на зло. Смысл заповеди для него состоял именно в том, что на зло никогда недопустимо отвечать злом. Зло же в его крайнем и существенном проявлении Толстой отождествлял с насилием. Заповедь непротивления накладывает абсолютный и безусловный запрет на применение насилия. Значение понятия насилия в интерпретации Толстого предельно расширяется.

Во-первых, насилием для него является как инициативное действие, направленное на разрушение другого (других), так и ответное действие, ограждающее этого другого (других) от разрушительного воздействия инициатора насилия. И инициативное проявление насилия, и силовое противостояние насилию, попытка защитить другого или самого себя в ситуации, когда другие средства недоступны, для Толстого есть насилие, т.е. безусловное зло. Во-вторых, в содержательном плане, помимо убийства, угрозы убийства или какоголибо внешнего воздействия, ущемляющего достоинство человека и/или наносящее ему разного рода ущерб, имеющего целью принуждение к чему-либо, Толстой также считает насилием совершение того, чего не хочет тот, над кем совершается насилие: «Но ведь властвовать значит насиловать, насиловать значит делать то, чего не хочет тот, над которым совершается насилие, и чего, наверное, для себя не желал бы тот, который совершает насилие; следовательно, властвовать значит делать другому то, чего мы не хотим, чтобы нам делали, т.е. делать злое» [12, с. 190-191]. Как указывает А. А. Гусейнов, это определение насилия для Толстого оказывается ключевым. В данной интерпретации насилие оказывается тождественным злу и прямо противоположным любви. Любить - значит, подчинять свою волю другому, насиловать - значит подчинять волю другого самому себе. Непротивление, ненасилие, отказ отвечать злом на зло и есть проявление любви, или как говорит А. А. Гусейнов, заповедь непротивления в трактовке Толстого, есть негативная формулировка заповеди любви [6, с. 287-288]. Из такого понимания насилия следует, что по существу любое действие, совершаемое против воли (желания) другого человека, тождественно насилию. Именно в таком понимании насилие есть зло как таковое и противоположно любви, которая предполагает подчинение собственной воли воле другого человека. Непротивление, ненасилие, отказ отвечать злом на зло, согласно Толстому, и есть проявление любви - единственной адекватной человеческой природе формы существования.

Если принять во внимание данные интерпретации насилия, заповедь непротивления в прочтении Толстого можно конкретизировать как запрет отвечать на зло а) убийством или угрозой убийства, каким-либо иным внешним воздействием, ущемляющего достоинство агрессора, б) совершением действий, которые на себе не хочет испытать тот, кто осуществляет насилие по отношению к другим, или которые направлены против его воли. Видимую нелепость последнего тезиса Толстой как будто бы устраняет, указывая на то, что не существует бесспорного, принимаемого всеми без исключения критерия зла, по которому можно узнать злодея: «...если бы и было разрешено богом употреблять насилие против злодеев, то каждый человек или общество людей стало бы признавать взаимно друг друга злодеями, что и есть теперь» [12, c. 27-28]. Вражда между людьми чаще всего возникает именно в силу того, что у них разные представления о добре и зле. И когда люди перестанут делить друг друга на добрых и злых, по убеждению Толстого, насилия в мире станет меньше.

Данное наблюдение Толстого чрезвычайно точно. Оно становится основанием для существенного аргумента в пользу отказа от борьбы с тем, что люди могут ошибочно принимать за зло в силу самых разных обстоятельств - в силу ограниченности возможно- 
стей познания, недостаточного понимания, по причине предрассудков, интеллектуальной и моральной лености, осознаваемого или неосознаваемого желания во что бы то ни стало отстоять свою собственную позицию, свой частный или даже корыстный интерес и т.п. Этот аргумент Толстого, в частности, обосновывает недопустимость применения разных форм насилия к инакомыслящим, вообще к другим просто потому, что они другие. Этот же аргумент указывает и на недопустимость навязывания другому собственного представления о благе, облагодетельствования другого против его воли. Однако, думается, все эти важные сами по себе соображения не имеют отношения к смыслу заповеди непротивления злу. В заповеди говорится о том, как человеку следует отвечать на конкретные, явно направленные лично против него действия. Толстой же здесь по сути предостерегает против совершения инициативных поступков в отношении людей, которые по тем или иным причинам кажутся субъекту этих поступков «злыми» или неразумными и не понимающими в чем состоит их благо.

Несмотря на утверждение об отсутствии бесспорного универсального критерия зла, сам Толстой его четко формулирует. Насилие и есть такой критерий - парадигмальное определение зла. Поэтому едва ли можно сомневаться в том, что тот, кто убивает или угрожает убийством, попирает достоинство другого, совершает зло. Согласно же Толстому, пока выражено намерение совершить зло, мы не можем знать наверняка, будет ли это намерение реализовано. И узнаем об этом, лишь когда зло уже совершилось. Но тогда применение силы окажется бессмысленным - оно никого не защитит, только увеличит количество зла в мире. Толстой был убежден в том, что применение силы или только угроза даже по отношению к инициатору насилия, направленное на пресечение конкретного насильственного действия, само является злом как таковым. Поэтому и в этом случае применение силы, с его точки зрения, не позволит преодолеть зло, а лишь приумножит его, т.е. усугубит проблему. Как нельзя огнем тушить огонь, водой сушить воду, так и злом невозможно уничтожить зло.

Из рассуждений Толстого становится очевидно, что он рассматривал проблему противостояния злу как проблему исключительно метафизического плана, т.е. как проблему очищения мира от зла, по возможности пол- ного, окончательного преодоления зла самого по себе и утверждения царства чистого беспримесного добра. Какими способами можно полностью и навсегда вытеснить зло из мира и жизни человека - вот вопрос, на который отвечал Толстой и решение которого он считал возможным не только в теории, но и в реальности. Вопрос же о том, как пресечь конкретное зло, а именно, насилие в отношении конкретного человека в конкретных обстоятельствах, как защитить конкретного другого от совершаемого над ним в данный момент зла (в том числе и насилия), сам по себе, вне общего контекста окончательной победы над злом, с точки зрения Толстого, является бессмысленным. Спасение человечества и мира от зла как такового, а не защита жизни и достоинства конкретного другого от угрозы со стороны реального злодея в конкретных обстоятельствах составляло непосредственный предмет его размышлений, ибо первое мыслилось им в качестве необходимого условия второго. Можно сказать по-другому: для Толстого вопрос о том, как обходиться с конкретным проявлением зла, следует рассматривать лишь в перспективе преодоления зла самого по себе. Если человек выбирает такой конкретный способ противостояния злу или пресечения зла, который этой перспективой однозначно не определяется, данный выбор не может быть оправдан с нравственной точки зрения и сам является злом.

Рассматривая проблему противостояния злу в метафизическом плане, Толстой фактически приписывал этот же подход своим оппонентам («Аксаковым и Соловьевым»), считавшим, что злу необходимо сопротивляться, в том числе с применением силы. Толстой полагал, что применение силы, а в его прочтении - насилия, они считают средством полного очищения от зла и утверждения добра. Между тем, в большинстве своем оппоненты Толстого решали гораздо более приземленную задачу - они отстаивали возможность применения силы для пресечения конкретного зла в исключительных обстоятельствах - когда все иные способы оказались неприменимыми. Один из главных вопросов для них - как здесь и сейчас защитить (спасти) конкретную жертву от посягающего на нее агрессора, которого в данных обстоятельствах ничто, кроме применения силовых средств, остановить не может и как при этом не выйти за рамки морально допустимого. Если предположить, что оппоненты Толстого допускали 
возможность окончательной победы над злом в земной жизни, то совершенно очевидно, они не мыслили ее вне решительного сопротивления реальным проявлениям зла.

Одна из особенностей понимания заповеди непротивления Толстого связана с трактовкой заповеди как безусловного закона прямого действия - закона, который не допускает никаких исключений, уточнений и оговорок: «Не противься злому - значит не противься злому никогда, т.е. никогда не делай насилия, т.е. такого поступка, который всегда противоположен любви» [9, с. 313]. Известны многие приводимые Толстым примеры, с помощью которых он стремился убедить в недопустимости применения силы, ее ненужности и главное - бесполезности при сопротивлении злу. Эти примеры, имеют важное значение для прояснения смысла учения Толстого, они делают это учение предельно ясным, однозначным, исключая тем самым возможность вариативности в интерпретации его морально-философских идей. Яркий поясняющий пример Толстой приводит в уже упоминавшемся письме Энгельгардту: «Все люди братья - одинакие. И если пришли Зулу, чтобы изжарить моих детей, то одно, что́ я могу сделать, это постараться внушить Зулу, что это ему не выгодно и не хорошо, - внушить, покоряясь ему по силе. Тем более, что мне нет расчета с Зулу бороться. Или он одолеет меня и еще более детей моих изжарит, или я одолею его, и дети мои завтра заболеют в мучениях худших и умрут от болезни. Расчета нет, потому что покоряясь я наверное делаю лучше, а сопротивляясь, я сомнительно делаю лучше» [10, с. 212].

Закон непротивления злу не может быть нарушен, даже когда речь идет о спасении конкретной человеческой жизни и даже о спасении жизни собственного ребенка. Примечательно, что Толстой обосновывал абсолютность заповеди непротивления исходя из признания безусловной ценности человеческой жизни, на которую недопустимо посягать ни при каких обстоятельствах: «Признание жизни каждого человека священной есть первое и единственное основание всякой нравственности» $[12$, с. 246]. Однако логика его рассуждения приводит к тому, что фактически признается лишь безусловная ценность жизни инициатора насилия, а ценность жизни его жертвы оказывается вторичной, ведь ради ее защиты недопустимо совершать ничего такого, чего не хочет агрессор. В данном примере он не хочет, чтобы ему помешали изжарить детей. Между тем, как было сказано выше, евангельская заповедь непротивления злу говорит о том, как себя вести человеку, в случае прямого предпринимаемого лично против него злонамеренного действия. В числе уточнений заповеди нет ни одного, в котором разъяснялось бы, как человеку следует поступать, если злонамеренные действия предпринимается в его присутствии по отношении к другому. Примеры же Толстого в большинстве своем призваны продемонстрировать тщетность и моральную ущербность попыток силой остановить злодея, посягающего на жизнь, здоровье, достоинство других людей.

Один из дополнительных аргументов, наиболее часто используемых Толстым в подтверждение бессмысленности применения силы в отношении агрессора, определялся вполне обоснованным гносеологическим скептицизмом: мы никогда не можем знать наверняка, спасая другого и применяя силу к агрессору, какую в действительности услугу оказываем жертве нападения. Как следует из последнего примера, вполне может оказаться, что для детей лучше быть зажаренными зулу, чем позже умереть в мучениях от подхваченной болезни. Нарушение абсолютного закона может обернуться худшими, нежели его строгое исполнение, последствиями для всех вовлеченных в ситуацию. Как было сказано выше, применение силы к агрессору также может оказаться неоправданным, ведь мы не можем знать наверняка, осуществит ли он свою угрозу. И если не осуществит, а моральный субъект применит силу, то поступок морального субъекта окажется сокрушительным не только для не состоявшегося агрессора, но и для самого морального субъекта: он утратит статус морального субъекта, сам превратиться в насильника. Невозможность обладания абсолютно достоверным знанием в отношении предполагаемого хода событий оказывается достаточным основанием невмешательства и для тех, кто способен руководствоваться в своих поступках, если не возвышенными моральными соображениями, то хотя бы здравым смыслом. Согласно Толстому, безусловное следование заповеди непротивления злу защищает морального субъекта от опасности совершить поступок, который не окупится никакими последствиями и который прямо или косвенно нанесет непоправимый ущерб другим людям и самому моральному субъекту, поскольку совершив такой поступок, он утра- 
тит свой моральный статус. Как показывает А. В. Прокофьев, этика ненасилия в целом, и учение о непротивлении злу насилием Толстого в частности, характеризуется определенными особенностями. Одна из основных - нацеленность на обеспечение возможности для человека избежать нравственного риска, или вовлеченности в ситуации, чреватыми для него утратой статуса морально безупречной личности. Такая утрата может случиться, если моральный субъект ставит свою репутацию в зависимость от внешних обстоятельств - обстоятельств, которых он всецело не контролирует. Этика ненасилия формулирует лишь такие задачи, решение которых полностью во власти человека. Например, неприменение силы ни в каких обстоятельствах. Спасение же другого от предполагаемого злодея к такого рода задачам не относится [8].

Может возникнуть впечатление, что для Толстого проблема борьбы со злом - насилием - вообще была неактуальной. Гораздо важнее для него - прояснить условия, при соблюдении которых эта проблема возникнуть не может. Главное условие состоит в том, что сам человек не должен совершать никакого насилия. В «Царствии Божием внутри вас» Толстой пишет: «Христианин ни с кем не спорит, ни на кого не нападает, ни против кого не употребляет насилия; напротив того, он сам беспрекословно переносит насилие; но этим самым отношением к насилию не только сам освобождается, но и освобождает мир от всякой внешней власти» [12, с. 169]. Однако утверждение о неактуальности для Толстого проблемы борьбы со злом было бы чрезмерно сильным. Толстой убежден в том, что только такое - терпимое - отношение к чужому насилию в сочетании с абсолютным отказом человека самому применять насилие в любых обстоятельствах по отношению ко всем людям, включая насильников, может освободить от насилия весь мир. Именно такой способ борьбы со злом является, с точки зрения Толстого, единственно возможным. Абстрактная логика данного рассуждения безупречна: если никто не будет совершать насилия, его не будет.

Толстой, тем не менее, не ограничивается общей рекомендацией терпеть насилие от других и никогда не совершать его самому. На основании его текстов можно выделить несколько морально обоснованных способов борьбы со злом. Во-первых, это забота о собственной душе, самосовершенствование. За- бота о душе требует принципиального отказа от насилия в любых его формах, утверждения порядка любви в своей душе. Поэтому самосовершенствование предполагает определенное - ненасильственное - отношение ко всем другим людям, включая врагов и обидчиков, прощение, примирение, любовь. Во-вторых, противостояние злу требует неучастия в тех формах деятельности, которые так или иначе предполагают применение насилия. К последним Толстой относил государственную, промышленную, церковную, образовательную, научную, эстетическую и др. виды деятельности, поскольку они не просто допускают, с его точки зрения, нарушение главного морального закона ненасилия, но опираются на насилие, возведенное в закон, и немыслимы без существования рабства. Чиновники, торговцы, церковники, люди науки, искусства и т.п. путем разных форм насилия присваивают себе труд простого народа, не принося ему никакой пользы, тем самым причиняют ему зло [11]. В-третьих, необходимо просвещение - разъяснение людям того, что насилие в любой своей форме преступно и попросту глупо, бессмысленно. Наконец, в-четвертых, в случае непосредственного столкновения с насилием, несущим прямую угрозу жизни людей (близким или ближним) Толстой не видит другого выхода, кроме обращения к здравому смыслу злодея, попытки внушить ему тщетность его намерений, невыгодность и неправильность для него самого его злонамеренного предприятия. В крайнем же случае допустимо попытаться заступиться за жертву, отдав за нее собственную жизнь. Лишь в этом, последнем, пункте Толстой говорит о ситуации столкновения с реальным злом и о возможном способе сопротивления ему.

Стратегия Толстого по противостоянию злу, не допускающему применения широко понимаемого насилия, состояла в отказе от зла, в неучастии в делах зла: «Прежде чем делать добро, - писал он, - мне надо самому стать вне зла, в такие условия, в которых можно перестать делать зло» [11, с. 242]. В такие условия должен поставить себя каждый человек и лишь тогда пространство проявления зла постепенно съежится, как шагреневая кожа, а добра, напротив, - будет расширятся, тем самым проблема преодоления зла и утверждения добра в мире будет решена. Толстой убежден, что для успешной победы над злом, нужно не бороться с ним в его реальных проявлениях или чинить ему препятствия, а побороть его 
в себе, сохранить чистоту собственной души и жить по законам добра, сформулированным в Евангелии, главные из которых вменяют: не оскорблять людей словом; воздерживаться от блуда, соблюдать чистоту брачной жизни; не клясться, вперед не обещать ничего людям; не платить злом за зло, терпеть обиды, отдавать рубаху; не делать зла врагам, говорить о них доброе, не делать различия между ними и своими согражданами [12, с. 8o].

Стратегия неучастия выглядит возвышенной, но ведет ли она к осуществлению той цели, которую сам Толстой считал главной утверждение мира без насилия? Отказ сопротивляться реальному злу при прямом столкновении с ним очевидно оборачивается потворством реальному злу, отчего его, разумеется, не становится меньше. Самопожертвование в противостоянии злу, мотивированное признанием требования не причинять другому того, чего он не хочет, даже если это злодей, открыто демонстрирующий свои намерения и решимость их осуществить, оказывается самопожертвованием не столько ради защиты или спасения жертвы, сколько ради самого злодея в его собственном качестве: устранив «защитника» жертвы, он сможет беспрепятственно вернуться к осуществлению своего намерения и реализовать его. Единственный «моральный выигрыш» в этой ситуации оказывается на стороне субъекта, не применившего силу против злодея, но пожертвовавшего собственной жизнью. Его статус морально безупречной личности оказывается подтвержденным, причем, подтвержденным навечно, если только исходить из того, что мораль по своему внутреннему смыслу требует от нас такого подтверждения прежде всего (a, скажем, не заботы о другом, которая в данном случае проявилась бы в защите другого от злодея). Моральный пафос позиции Толстого растворяется на глазах: если самопожертвование ради собственных убеждений вызывает восхищение, то фактическое принесение в жертву жизни других ради верности собственным убеждениям или подтверждения собственного морального статуса, с моральной точки зрения, кажется сомнительным.

$$
* * *
$$

Смысл заповеди непротивления в интерпретации Иосифа Бродского определяется прежде всего иным, нежели у Толстого, пониманием зла. Бродский исходит из того, что зло, как и добро, неустранимо («Мир несовершенен. Золотого века никогда не было и не будет» $[4$, c. 115]), оно представляет собой непреодолимое обстоятельство человеческой жизни, «ощутимую социальную реальность» [2, с.275], часто неподвластную нашему контролю. Эта реальность многообразна, она принимает формы, необязательно крайние, в которых зло опознавалось бы безошибочно. Часто зло выступает в «наряде добра", что усугубляет проблему его идентификации. При таком понимании метафизический вопрос о способах окончательной победы над злом снимается сам собой. А рекомендация Толстого «встать вне зла» и попытаться сохранить моральную чистоту, направив все усилия на самосовершенствование, оказывается неуместной и неисполнимой. По убеждению Бродского, никакие усилия в этом направлении - ни забота о душе, ни хитрый расчет не смогут предотвратить встречу со злом, для каждого человека она неизбежна. Поэтому чрезвычайно важно направить усилия не на поиск способов уклонения от встречи со злом и сохранения собственной моральной безупречности, а на понимание того, как вести себя при непосредственном столкновении с реальным злом, как уйти со «свидания» с ним с наименьшими для себя моральными потерями. Таким образом, позицию Бродского определяет убежденность в неустранимости зла и понимание того, что реальное зло многолико. Он не озабочен вопросом окончательной победы над злом, для него ключевая проблема - как распознать зло и что можно противопоставить его конкретным проявлениям в реальных жизненных обстоятельствах.

Интересно, проследить различие ключевых установок в отношении заповеди непротивления злу Гроция, Толстого и Бродского. Гроций понимает заповедь непротивления злому как рекомендацию для поведения «в делах, которые несильно могут нас затруднить», когда мы можем позволить себе «не настаивать на своем праве». Иными словами, эта заповедь, в представлении Гроция, призывает нас уступать не столько закоренелому злодею, посягающему на наше достоинство и жизнь, сколько обидчику, уступать, не превышая допустимой меры, и в непринципиальных для нас вопросах. Заповедь настраивает человека на миролюбивый лад. При этом Гроций не ставит под сомнение необходимости борьбы со злом в более серьезных его формах и выстраивает теорию такой борьбы. По его убеждению, «уго- 
ловные наказания и оружие, отражающее насилие, по природе заслуживают одобрения и относятся к добродетелям справедливости и благотворительности» [5, с. 97].

Толстой воспринимает заповедь непротивления как абсолютную, действующую невзирая на обстоятельства и вовлеченных в них людей. Для Толстого она одинаково безапелляционна в ситуациях, когда человек нападает, и когда защищается, когда злонамеренное действие направлено против морального субъекта (и возможно сокрушительно для него), и когда оно направлено на людей, которых перед его глазами «мучают и убивают» и которые молят его о помощи [10, с. 114]. В интерпретации Толстого заповедь представляет собой правило и повседневной индивидуальной жизни, и общественной.

Бродский же в «Актовой речи» предлагает принципиально иной взгляд на заповедь. Он демонстрирует ее действие в ситуации (а) прямого личного столкновения со злом, (б) такого столкновения, при котором не настаивать на своем праве нельзя. Следование заповеди оказывается способом утверждения собственного права - права на человеческое достоинство в условиях, предполагающих его унижение и полное уничтожение. Наконец, Бродский говорит о ситуации, в которой (в) единственное, чем располагает человек для противостояния злу, - это его тело, одежда и способность пройти какой-то путь, в то время, как противник располагает всеми средствами подавления, какие только может пожелать.

Для иллюстрации одной из возможных практических интерпретаций заповеди Бродский рассказывает историю, которая по всей вероятности случилась с ним самим. Дело было, видимо, в одной из пересыльных тюрем по пути к месту ссылки. Как-то утром дверь камеры распахнулась, и надзиратель объявил заключенным о том, что коллектив тюремной охраны вызывает заключенных на социалистическое соревнование по рубке дров, которые в огромном количестве скопились на тюремном дворе. Необходимость освобождения двора была очевидной без всякого соревнования. Молодой заключенный спросил: «А если я откажусь?». Надзиратель ответил: «Тогда без еды». Всем раздали топоры, и рубка началась. К обеду и заключенные, и охранники выбились из сил. Был объявлен перерыв. Все сели есть, кроме задавшего вопрос. Он продолжал рубить дрова. После перерыва работу возобновили, «но пыл поослаб». Че- рез какое-то время кончилась смена у охраны, потом остановились и арестанты. А молодой человек все продолжал рубить дрова. Сначала над ним подсмеивались, через какое-то время и арестанты, и охранники стали уговаривать его бросить работу, но он продолжал. К концу дня уже никто не иронизировал и не смеялся: «ухмылки сменились на их лицах сперва замешательством, потом ужасом». В семь тридцать он прекратил, дошел до камеры, рухнул на кровать и уснул. После этого, пока он был в той тюрьме, к социалистическому соревнованию между охраной и арестантами больше не призывали, хотя дрова по-прежнему скапливались во дворе [2, с. 277-278].

Бродский приводит эту историю как пример эффективного противостоянию злу в соответствии с заповедью непротивления в заведомо проигрышных для жертвы условиях. Әффективность выражалась не только в том, что молодой заключенный сумел отстоять и утвердить свое достоинство, но и в том, что он добился прекращения принуждения - и не только в отношении себя, но и в отношении солагерников. Эта борьба носила экзистенциальный (а не моральный) характер: поступок не был рассчитан ни на какой моральный урок: обидчики и притеснители остались в своем качестве - обидчиками и притеснителями, они не раскаялись, не пережили угрызений совести и чувства вины, не примирились с жертвой. Но они пережили «замешательство и ужас» и отступили. Один бесправный заключенный продемонстрировал им способность действовать по своим собственным правилам, и тюремщики отказались от попыток навязать ему свои - никаких социалистических соревнований больше не устраивалось.

Мысль Бродского можно понять так, что в подобных ситуациях следует не столько стремиться к утверждению добра в полном смысле слова, сколько пытаться пресечь поползновения зла, поставить ему преграду. Перефразируя цитату из «Речи на стадионе», можно сказать: задача человека в данном случае состоит не столько в том, чтобы понравиться ангелам, сколько в том, чтобы нанести урон демонам [4, с. 118]. И дело вовсе не в том, что Бродский придерживается заниженных моральных стандартов, а в том, что в определенного рода ситуациях это большее, чего можно достичь.

В отношении примера Бродского возможны возражения. Можно обратить внимание на то, что в действительности описанная ситуация достаточно мягкая и безопасная, здесь нет 
настоящих злодеев, как и зла в собственном смысле слова, жертве никто всерьез ничем не угрожал. Это ли угроза - «без еды»? Более того, надзиратели и охранники принуждали заключенных не ради того, чтобы унизить их, насладиться проявлением своей над ними власти, они всего лишь решали хозяйственную задачу освобождения двора от дров. При этом сами принимали участие в работе и скорей всего наколотыми дровами отапливалась тюрьма. Можно также задаться вопросом: В чем состояла эффективность предложенного Бродским поведения в отношении зла? Даже если на какое-то время «социалистические соревнования» в той тюрьме отменили, едва ли их отменили навсегда. Можно также заметить, что если всерьез рассматривать данный случай как принуждение, он скорее попадает под описание Гроция, т.е. относится к ситуациям, когда следует уступить, показывая тем самым обидчику свое миролюбие и призывая его к тому же.

Вероятно последнее утверждение отчасти правильно. Действительно, герой истории Бродского в ответ на принуждение вместо одного поприща, проходит два или три - не сто и даже не десять. Однако, делает он это не ради демонстрации надзирателям и охранникам своего миролюбивого настроя и готовности уступать и дальше (что в данных обстоятельствах было бы глупо), а отстаивая свое человеческое достоинство и выражая решимость бороться за него и впредь. Человеческое достоинство для Бродского - «понятие абсолютное, а не разменное» [4, с. 117]. Именно поэтому, с его точки зрения, любые попытки ущемлять достоинство, следует пресекать. Пусть в действиях тюремщиков, не было явно злого намерения притеснить или унизить заключенных, но их действия по существу своему были ничем иным, как принуждением бесправных людей, находящихся в полной их власти. Для Бродского такое принуждение бесправных, даже не в самой жестокой форме, есть одно из несомненных проявлений зла, уступать которому недопустимо хотя бы из благоразумия - по причине склонности зла к распространению. Позиция Бродского состоит в том, что зло многолико, и совсем неважно, в какой форме оно проявляется - в явной или скрытой, в мягкой или жестокой - ему необходимо сопротивляться, давать решительный отпор. Если в каком-то конкретном случае зло удается пресечь, это не значит, что даже в этом конкретном случае победа над злом одержана навсегда, однако территория у него, пусть и на время, будет отвоевана. Скажем, даже если тюремщики отказались от «социалистических соревнований», пока в тюрьме находился герой истории, отсюда не следует, что они оказались от таких соревнований навсегда. Вполне возможно, пройдет время и все повторится вновь. Это свидетельствует не о том, что поступок молодого заключенного оказался бессмысленным, а о том, что зло неустранимо и борьба с ним должна быть непрерывной. Появятся другие люди, которые по мере собственных сил и возможностей будут противостоять ему.

Бродский предупреждает о том, что опыт борьбы со злом предельно индивидуален и, разумеется, не предлагает свой пример в качестве общего рецепта и тем более в качестве образца. Во-первых, навязывать свои рецепты - дело сомнительное, с моральной точки зрения. Каждый человек принимает свое решение сам и несет все, связанные с этим решением тяготы, тем более, когда находится в «безнадежно проигрышной ситуации». Никаких общих рецептов здесь быть не может еще и потому, что сопротивление злу не поддается клишированию. Бродский предлагает именно пример, который всего лишь иллюстрирует одну из возможных практических интерпретаций заповеди непротивления злу. Таких интерпретаций может быть множество: чем «находчивее, неожиданнее и предприимчивее» жертва, тем больше у нее шанс на успех.

Замечание Бродского о важности индивидуализированного ответа на проявления зла имеет еще и тот смысл (не проговариваемый Бродским), что способ сопротивления зависит и от той формы, в какой зло проявляется (притеснение, обида, подавление, унижение, угроза, в том числе убийства и т.п.), от того, на кого это зло направлено (на самого человека или на других), от его масштабов (является ли зло в лице одного злодея или государстваагрессора), от реальных возможностей столкнувшегося со злом, от конкретной ситуации, в которой это столкновение происходит и т.д. Сама заповедь может быть использована не во всех обстоятельствах, она не универсальна и не абсолютна.

Иными словами, заповедь непротивления злу Бродский рассматривает как один из рецептов поведения на «свидании» со злом. Этот рецепт в его интерпретации предписывает активную или даже «агрессивную» борьбу против зла, в том числе в ситуации заведомо 
неравной борьбы. В такой ситуации адекватное понимание смысла заповедуемого оказывается жизненно важным. Цена неправильного прочтения заповеди может оказаться чрезвычайно высокой. В понимании заповеди непротивления злу встречаются ошибки, и Бродский предостерегает против них.

Во-первых, он указывает на недопустимость сведения смысла заповеди к непротивлению злу как таковому. Именно в этой редукции он видел фундаментальную ошибку Толстого. Возможно, абстрактно логика Толстого - если каждый не будет совершать насилия, насилие исчезнет само собой - является безукоризненной. Однако в реальности данный подход оборачивается ничем иным, как попустительством злу, расширением его границ, усилением его позиций и «отсрочкой понимания его слабостей». Непротивление как таковое не обеспечивает ни реальной победы над злом, так как чаще всего агрессор воспринимает непротивление жертвы как гарантию собственной безнаказанности, ни моральной победы. Уязвимость моральной позиции непротивления с этой точки зрения состоит, в частности, в том, что, не противясь злому, непротивленец искушает агрессора, провоцирует его на продолжение злонамеренных действий. Другую существенную причину моральной сомнительности победы непротивленца Бродский видел в том, что такая победа как будто «делает жертву выше, то есть лучше, ее врага». Но зло зарождается именно тогда, когда кто-то начинает считать себя лучше другого: «И вот почему, в первую очередь, вас ударили по правой щеке» [2, с. 277].

Во-вторых, недопустимо моралистическое и политическое прочтение заповеди непротивления злу. Заповедь непротивления - это не моральное правило на каждый день и не принцип устройства общества или ведения политической борьбы. Христос был не просто человеком, но и божественным духом, и уже сам этот факт указывает на уязвимость такой трактовки заповеди непротивления, какую предлагал, например, Толстой, призывая отнестись к ней как к самому простому и ясному практическому учению о том, как надо жить всем людям. Бродский считает, что моралистическое или политическое прочтение заповеди непротивления злу либо ведет к гибели непротивленца, либо уготавливает ему судьбу «духовного буржуа» (с «членством в гуманистических организациях и неправительственных организациях»), который наслаждается «комфортом собственных убеждений», развивая свои идеи в тиши уютного кабинета вне опасной ситуации столкновения с реальным злом.

Бродский настаивает на экзистенцииальном понимании заповеди непротивления злу. Такое понимание предполагает, что руководствующийся заповедью человек, не стремится пробудить в обидчике и притеснителе совесть, чувство вины (подавить которое ему ничего не стоит), не апеллирует к его моральному чувству, ни призывает к примирению и т.п. Своим поведением этот человек «навязывает его чувствам и уму бесцельность всего предприятия» [2, с. 278]. Агрессор, разумеется, не испытывает никаких угрызений совести, но чувствует свое бессилие.

Опираясь на рассуждения Бродского, можно выделить два основных условия корректного, с его точки зрения, понимания заповеди непротивления злу. Первое связано с осознанием природы зла. Несмотря на неустранимость зла, его повсеместность, оно вторично, несамодостаточно, поэтому и стремится к поиску союзников, к обретению прочного фундамента. Именно поэтому эффективность борьбы со злом предполагает предельный индивидуализм, самостоятельность мышления и даже эксцентричность. Эффективный ответ на зло должен оказаться непредсказуемым для обидчика, он должен обескуражить его, выбить почву из-под его ног, заставить «пережить замешательство и ужас». Второе условие требует воспринимать заповедь в полноте и целостности, что означает не сводить все ее содержание к требованию всякий раз подставлять агрессору для удара вторую щеку, но принимать также предписания, касающиеся рубашки с верхней одеждой и двух поприщ. Целостное восприятие заповеди позволяет интерпретировать ее как указание на возможность обессмыслить зло чрезмерностью, демонстрацией ничтожности его запросов. Такая позиция, по убеждению Бродского, ставит жертву в положение активного «духовного агрессора», не устраняющегося от зла, а вступающего в прямой контакт со злодеем и силой (то есть вопреки желанию) задающему собственные правила игры.

Если сравнивать позиции Бродского и Толстого в отношении заповеди непротивления злу, то можно заметить, что хотя их изначальные установки противоположны, оба призывают к решительной борьбе со злом. Толстой считает, что заповедь непротивления злу требует не противиться лишь внешнему злу, и указывает на необходимость для человека бороться со злом внутри само- 
го себя. Бродский, не разделяя точку зрения Толстого, показывает, что непротивление любым формам зла оборачиваются его распространением и как правило проникают во внутренний мир даже искреннего непротивленца. В отличие от Толстого Бродский понимает заповедь непротивления злу не как завет самосовершенствования, а как один из рецептов борьбы с реальными проявлениями зла. Саму борьбу он признает важной и неотложной. Она, в представлении Бродского, предполагает перехват инициативы у злодея, принуждение его играть по своим правилам или хотя бы непозволение навязывать свои. Заповедь непротивления злу, по убеждению Бродского, призывает не воздавать добром за зло, а совершать в отношении притеснителя, обидчика и т.п. именно то, чего он не хочет, что направлено на решительное пресечение злых проявлений его воли здесь и сейчас.

На мой взгляд, один из важных уроков, который следует из рассуждений о заповеди непротивлении злу Толстого и Бродского, состоит в осознании того, что борьба со злом как таковым вне борьбы с реальными проявлениями зла едва ли возможна. Рассуждение о непротивлении в отрыве от попытки ответить на вопрос о способах и формах противостояния реальным проявлениям зла нивелирует моральную ценность непротивления. Непротивление как стратегия и тактика противостояния реальным проявлениям зла для того, чтобы быть успешной, требует в каждом отдельном случае вдумчивого осмысления, в ходе которого будут приняты во внимание множество важных подробностей, в том числе и все возможные последствия, за которые непротивленец несет ответственность. В первую же очередь он несет ответственность за жизнь и благополучие других людей, для которых чей-то ригоризм в осуществлении принципа непротивления может обернуться значительными, а возможно и фатальными потерями.

\section{Библиография:}

1. Апресян Р.Г. «Мне отмщение и Аз воздам»: О нормативных контекстах и ассоциациях заповеди «Не противься Злому» // Этическая мысль, 2007. Вып. 7. С. 62-82.

2. Бродский И. А. Актовая речь / Пер. с англ. Д. Дашевского // Бродский И.А. Соч. в 7 т. Т. 5. СПб.: Пушкинский фонд, 2001. С. 275-280.

3. Бродский И.А. Похвала глупости / Пер. Е.Касаткиной // Бродский И.А. Соч. в 7 т. Т. 6. СПб.: Пушкинский фонд, 2003. С. 86-92.

4. Бродский И.А. Речь на стадионе / Пер. Е.Касаткиной // Бродский И.А. Соч. в 7 т. Т. 6. СПб.: Пушкинский фонд, 2003. С. 112-119.

5. Гроций Г. О праве войны и мира. М.: Ладомир, 1994. С.

6. Гусейнов А.А. Л.Н. Толстой: Непротивление злу насилием // Гусейнов А.А. Великие пророки и мыслители. Нравственные учения от Моисея до наших дней. М.: Вече, 2009.

7. Плешаков К. Бродский в Маунт-Холиоке // Журнальный зал [Электронный ресурc] URL: http://magazines. russ.ru/druzhba/2001/3/plesh.html (дата обращения: 26.10.2015).

8. Прокофьев А.В. Этика ненасилия как бегство от нравственного риска // Философия и культура, 2011, № 7. С. $137-149$

9. Толстой Л.Н. В чем моя вера? // Толстой Л.Н. Полн. собр. соч. Т. 23. М.-Л.: Государственное издательство художественной литературы, 1957.

10. Толстой Л.Н. Письмо М.А. Энгельгардту // Толстой Л.Н. Полн. собр. соч. Т. 63. М.-Л.: Государственное издательство художественной литературы, 1934. С.114-115.

11. Толстой Л.Н. Так что же нам делать? // Толстой Л.Н. Полн. собр. соч. Т. 25. М.-Л.: Государственное издательство художественной литературы, 1937.

12. Толстой Л.Н. Царство Божие внутри вас // Толстой Л.Н. Полн. собр. соч. Т. 28. М.-Л.: Государственное издательство художественной литературы, 1957.

\section{References (transliterated):}

1. Apresyan R.G. «Mne otmshchenie i Az vozdam»: O normativnykh kontekstakh i assotsiatsiyakh zapovedi «Ne protiv'sya Zlomu» // Eticheskaya mysl', 2007. Vyp. 7. S. 62-82. 
2. Brodskii I. A. Aktovaya rech'/ Per. s angl. D. Dashevskogo // Brodskii I.A. Soch. v 7 t. T. 5. SPb.: Pushkinskii fond, 2001. S. 275-280.

3. Brodskii I.A. Pokhvala gluposti / Per. E.Kasatkinoi // Brodskii I.A. Soch. v 7 t. T. 6. SPb.: Pushkinskii fond, 2003. S. 86-92.

4. Brodskii I.A. Rech' na stadione / Per. E.Kasatkinoi // Brodskii I.A. Soch. v 7 t. T. 6. SPb.: Pushkinskii fond, 2003. S. 112-119.

5. Grotsii G. O prave voiny i mira. M.: Ladomir, 1994. S.

6. Guseinov A.A. L.N.Tolstoi: Neprotivlenie zlu nasiliem // Guseinov A.A. Velikie proroki i mysliteli. Nravstvennye ucheniya ot Moiseya do nashikh dnei. M.: Veche, 2009.

7. Pleshakov K. Brodskii v Maunt-Kholioke // Zhurnal'nyi zal [Elektronnyi resurs] URL: http://magazines.russ.ru/ druzhba/2001/3/plesh.html (data obrashcheniya: 26.10.2015).

8. Prokof'ev A.V. Etika nenasiliya kak begstvo ot nravstvennogo riska // Filosofiya i kul'tura, 2011, № 7. S. 137149

9. Tolstoi L.N. V chem moya vera? // Tolstoi L.N. Poln. sobr. soch. T. 23. M.-L.: Gosudarstvennoe izdatel'stvo khudozhestvennoi literatury, 1957.

10. Tolstoi L.N. Pis'mo M.A. Engel'gardtu // Tolstoi L.N. Poln. sobr. soch. T. 63. M.-L.: Gosudarstvennoe izdatel'stvo khudozhestvennoi literatury, 1934. S.114-115.

11. Tolstoi L.N. Tak chto zhe nam delat'? // Tolstoi L.N. Poln. sobr. soch. T. 25. M.-L.: Gosudarstvennoe izdatel'stvo khudozhestvennoi literatury, 1937.

12. Tolstoi L.N. Tsarstvo Bozhie vnutri vas // Tolstoi L.N. Poln. sobr. soch. T. 28. M.-L.: Gosudarstvennoe izdatel'stvo khudozhestvennoi literatury, 1957. 